Fourth International Conference on Sustainable Construction Materials and Technologies http://www.claisse.info/Proceedings.htm

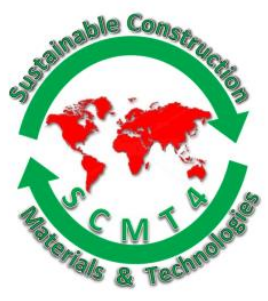

SCMT4

Las Vegas, USA, August7-11, 2016

\title{
Sustainable Construction Materials in (Bait Al-Sha'r) and Modern Trends in Saudi Arabia
}

\author{
Moshira El Rafey ${ }^{1}$, and Rehab Al Mulhem ${ }^{2}$ \\ ${ }^{1}$ Ph.D at Effat University, Architecturre Department, Jeddah, KSA, 11 Mohamed Farid Wagdi \\ Str., Al Manial Cairo Egypt. Email: <moshirar@gmail.com>. \\ ${ }^{2}$ Ph.D at Princess Nourah University, Head of Interior Design Department, Riyadh, KSA. \\ Email: 〈rihab_elmulhem2@hotmail.com>.
}

\begin{abstract}
Historically Saudi Arabia has experienced drastic urban changes since the late 1930s until the present day. A conflict between traditional cultural values and the introduction of modern physical urbanization was very limited at the beginning of this era; the native people have tried to follow their traditional and cultural habits and implement it in their daily lives today, especially their homes Bait Al Sha'ar known to be one of the best sustainable buildings providing cold environment during the summer and warm interior environment during the winter.

This research studies the different materials that are used in construction desert dwelling (Bait Al Shaar) in the Kingdom of Saudi Arabia using Al-Jouf city as an example in terms of the home design, home orientation, local material use and the way of maintaining quality and durability while achieving sustainability and how the construction materials of Beit Al Shaar can be reused in the new buildings and infrastructure using innovative ways to meet their needs. It sheds the light on innovative and non-traditional materials to fit the technology era and the rapid pace of economic changes in the Kingdom of Saudi Arabia. The research objective is to investigate new phenomena that have been perceived by the researchers. The new Bait Al Shaar shape and place in the courtyard and gardens of the new modern houses in the urban cities in the Kingdom of Saudi Arabia and it is used by the local residents to meet their needs. The aim is to discover the new phenomena of the use and the quality of life of Bait Al Shaar today. The result of this research indicates the use of these dwellings (Bait Al Shaar) have dramatically decreased although they are still a part of the traditional heritage in the Kingdom of Saudi Arabia and how they are still used as a sustainable environment preserving design heritage and the country' national identity.
\end{abstract}

\section{INTRODUCTION}

Historically Saudi Arabia has experienced drastic urban changes since the late 1930s until the present day. A conflict between traditional values and the introduction of modern physical urbanization was very limited at the beginning of this century; the native Saudis have tried to follow their traditional habits and implement 
it in their daily lives today, especially their homes Bait Al-Sha'r. This conflict between traditional values and the new urbanization in their minds is considered to be the beginning of physical modern trends, especially as it is related to the use of construction' materials.

This paper studies the traditional Saudi old house (Bait Al-Sha'r) construction materials in the Kingdom of Saudi Arabia using Al-Jouf city as an example in terms of the house design, house orientation, local construction materials use, and how the native residents in Saudi Arabia have adapted their lives to fit the modern physical urbanization and how they are still keeping up strong ties to their tribal beliefs and traditional heritage in their houses.

This paper also discusses the concepts of space components, construction materials, and space overlapping of their houses called (Bait Al-Sha'r) which used to be in the old times their dwellings. It is a fact that these three components are a reflection of the social and economic status of the old saudi house, (Bait Al-Sha'r). In addition this paper points out how these (Bait Al-Sha'r) were environmentally friendly due to their sustainable construction materials.

Furthermore, it should be added that the rapid pace of economic changes in the Kingdom of Saudi Arabia since the middle of the twentieth century destroyed gradually the traditional foundations of the Saudi economic life, forcing them to seek employment in the new urbanized towns and oil industries to supplement their incomes. The oil industry created new opportunities for them to be employed as laborers, drivers and guides. That is, rapid urbanization opened up different kind of jobs for them. Also, the government employed them as policemen, soldiers and guards. It has also launched agricultural settlement programs for them, concentrating them in villages, and supplying them with permanent water supplies and lands to cultivate. Thus, in Saudi Arabia today; the imports of cheap meat from abroad to feed the growing urban population weakened the economic base of the old saudi tribes.

\section{RESEARCH OBJECTIVES}

The objective of this paper is to investigate new phenomena that have been perceived by the researchers which is the new (Bait Al-Sha'r) shape, place and construction materials in the courtyard and gardens of the new modern houses in the urban cities in our case it is the (Al Jouf city) in the Kingdom of Saudi Arabia. The aim is to discover the new phenomena of the use and the quality of life of (Bait Al-Sha'r) today and to investigate the importance of maintaining the (Bait Al-Sha'r) as a traditional way of saving the cultural heritage of the Kingdom of Saudi Arabia. The major question that this research is investigating is: Why do residents in the modern urbanized cities built (Beit Al-Sha'r) in their courtyard or garden and how do they use it, and how new spaces in their modern houses are generated by the idea and practice of old traditional values?

\section{LITERATURE REVIEW}

History and Ethnic Relations of the Old Saudi Residents. The old Saudi residents of (Bait Al-Sha'r) are desert people in Saudi Arabia and the Middle East who used to move from place to place with their goats, sheep and camels. They tended to travel to find food for their animals. Their economic adaptation depended upon a variety of resources that are acquired from a variety of economic pursuits such as small-scale cultivation, trade, crafts, or other activities.

They, also followed their herds where they can find plants. They ate dates and milk, yoghurt, meat and cheese from animals and traded wool for other goods such as tea and other foods they might need. Also, camel breeding has traditionally been their primary economic activity as well as raising sheep and goats are the dominant activity for them. 
In 1900 in Saudi Arabia, they made up 40 percent of the population. By 1970 they made up only 11 percent. Their existence was diminished by the creation of nation states in the 1950s and the oil wealth. Today, they are faced with challenges in their lifestyle, as their traditional Islamic, tribal culture has begun to fade due to the new urbanization system in the Kingdom.

Description of (Bait Al-Sha'r) or (House of Hair). The size of the interior spaces of The (Bait Al-Sha'r) was made to be quickly raised in one location and then just as rapidly demolished and transported to a new location. It gets its name from the black goat's hair used to weave its covering and they are spread in the desert and along the fringes of rural towns.

Traditionally, the (Bait Al-Sha'r) or (house of hair), was divided into three sections by curtains (Al Gateh): the men's section, the family section and the kitchen's section. In the men's section, guests are received around the fireside where the host prepares coffee on the fire. This is the center of their social life. Furthermore, the serving of food and drink represents the generous hospitality of the host. It should be added that women occupy a very important position in this society. Not only do they raise the children, herd the sheep, milk the goats, cook, spin yarn and make the clothes, but they also weave the materials used for building (Bait Al-Sha'r)

Bait Al-Sha'r's construction materials are made out of wool that is woven into strip sheets that are then sewn together. The resulting rectangle is raised on poles, with ropes (Al-Atnab) used to create tension and secure the structure from the outside. Another piece of fabric hangs like a wave at the back (Bait Al-Sha'r) at night or during storms. The coloring of stained black comes from the natural color of the goats' hair. The loose weave allows for the treatment of the heat, and despite its dark color, it is typically $10-15^{\circ} \mathrm{C}$ cooler inside than outside during the day. The (Bait Al-Sha'r) was made to be quickly raised in one location and then just as rapidly demolished and transported to a new location. It gets its name from the black goat's hair used to weave its covering and they are spread in the desert and along the fringes of rural towns.

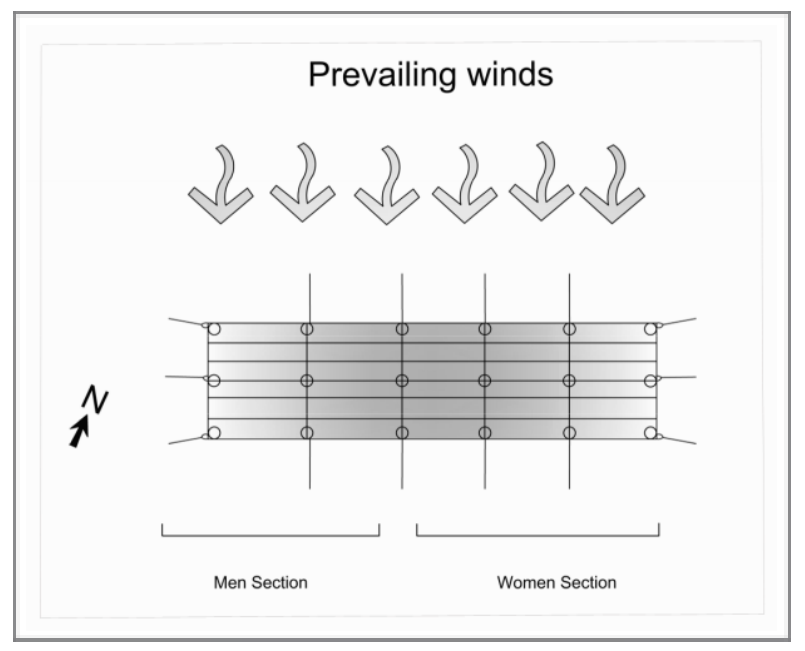

Figure 1. Plan of (Bait Al-Sha'r)

In addition to that, very little studies evaluated the materials used in the (Bait Al-Sha'r) and their positive effect on the sustainable environment. It should be added that, when it rained, the moisture expanded the material covering (Bait Al-Sha'r) closing the gaps in the weave and keeping out water. The fabric lasts about five years, and sections are replaced as they wear out. Furthermore, during the hot weather, the sides were rolled up to allow the free circulation of air without admitting sunlight. In cold weather; temperatures on winter nights in some parts of Saudi Arabia can drop below freezing, the cover is drawn across the open end of the (Bait Al-Sha'r) completely enclosing it and creating a warm environments for its inhabitants. 
The "houses of hair" or (Bait Al-Sha'r). It should be added that in the old times women were the builder of (Bait Al-Sha'r) and they are still building it today in their modern houses using it for other purposes. As for the structure of (Bait Al-Sha'r), it was made out of wooden poles that support the roof. It is pitched in an east-west in an aero-dynamic shape line in order to avoid the direct heat of the sun and to let air flow inside.

Size and Design of (Bait Al-Sha'r). (Bait Al-Sha'r) is often physically divided into two major sections by using fabric dividers (Al Gateh), decorated with different colorful patterns called "Al Safe", "Al Tayarah"; each of these patterns represents a tribe. The first section is men's section and is used for entertaining guests and other tribes' men. It includes a fireside, a diversity of rugs, cushions and camel saddles (Al kharg). One of the more important activities carried out on this side of the (Bait Al-Sha'r) is the preparation of coffee for consumption by guests and friends. In general, the men's section of the black (Bait Al-Sha'r) contains fewer material culture items than the women's side. Most household chores, like cooking, are carried out in the second section (women's side) of the structure, where domestic items are stored. Furthermore, the division of the (Bait Al-Sha'r) into two major parts is a reflection of the residents' cultural habits: the men's part of the is associated with the public aspects of the society, while the women's side is restricted to private aspects of life. Furthermore, the gendered division of space inside the (Bait AlSha'r) is attributed to Islamic beliefs and customs that determine how space is used.

Also, the size of (Bait Al-Sha'r), it varied from one section to five spaces depending on the owner economic status and the number of family members. The average (Bait Al-Sha'r) is made up of three sections as mentioned earlier, men, women and kitchen. Thus, the size reflects the importance of the owner or the size of his family. The widths vary also according to their everyday needs. Thus, the (Bait Al-Sha'r) is an indicator of how traditional life was a part of the Saudi traditional way of living. In sum, providing shelter and hospitality to their inhabitants, it was the focus of their life, as well as an important part of Saudi culture. Furthermore regarding the sustainable environment side of The (Bait Al-Sha'r), it was made to be quickly raised in one location and then just as rapidly demolished and transported to a new location. It gets its name from the black goat's hair used to weave its covering and they are spread in the desert and along the fringes of rural towns. Traditionally the material of the (Bait Al-Sha'r) is woven from the hair of a black goat, making a loosely woven cloth that allows air to pass through, while providing shade in hot and arid climates.

In addition, the black wool of the black goat hair absorbs heat and the loose materials lets the heat scatter making the interior much cooler between 10 and 15 degree centigrade then the outside, thus, because the material is woven loosely, it allows heat distribution. We must add; that when the materials get wet from the rain the fibers increase in size and prevent the rain leaks. The (Bait Al-Sha'r) is designed in a way that can fit both hot and cold weather. In sum, the basic interior space of the Beit Al-Sha'r is covered with a long, narrow strip of heavy material and the (Bait Al-Sha'r) floor was the desert itself, sometimes covered by locally woven rugs (Sahah).

As mentioned earlier a brightly decorated divider (Al Gateh) hangs inside across the middle of the The (Bait Al-Sha'r) was made to be quickly raised in one location and then just as rapidly demolished and transported to a new location. It gets its name from the black goat's hair used to weave its covering and they are spread in the desert and along the fringes of rural towns.

To divide it into sections. The women's section is the larger than men section; it contains food stores, cooking utensils. Furthermore, (Bait Al-Sha'r) dividers vary from region to region and from tribe to tribe, although that is not as true now as it was when there were more nomads on the move. In earlier times, one could identify the tribe by seeing the (Bait Al-Sha'r) divider's designs and colors. With more desert residents settling and taking jobs in the rapidly urbanized changing cities, there are fewer tribal distinctions in style and color of weavings.

Flexibility of the Interior Space Planning in (Bait Al-Sha'r). There are distinct characteristics that are fundamental of the Saudi traditional house in the desert or (Bait Al-Sha'r). The internal organization 
for example, divides the house into two main sections. The first is the living quarter designed for the use of closely related members of the family, particularly the female members. The second area is designed for male visitors and guests. This area is arranged so as to be independent from the rest of the house thereby allowing male visitors easy access without disrupting the privacy of female householders. These two part are divided by dividers (Al Gateh). Moreover, the two areas can be extended through the flexibility of the way the dividers (Al Gateh). Also, the exterior wall (Al Ruaag) can be easily moved to provide more spaces and more privacy according to the needs of the residents living in it.

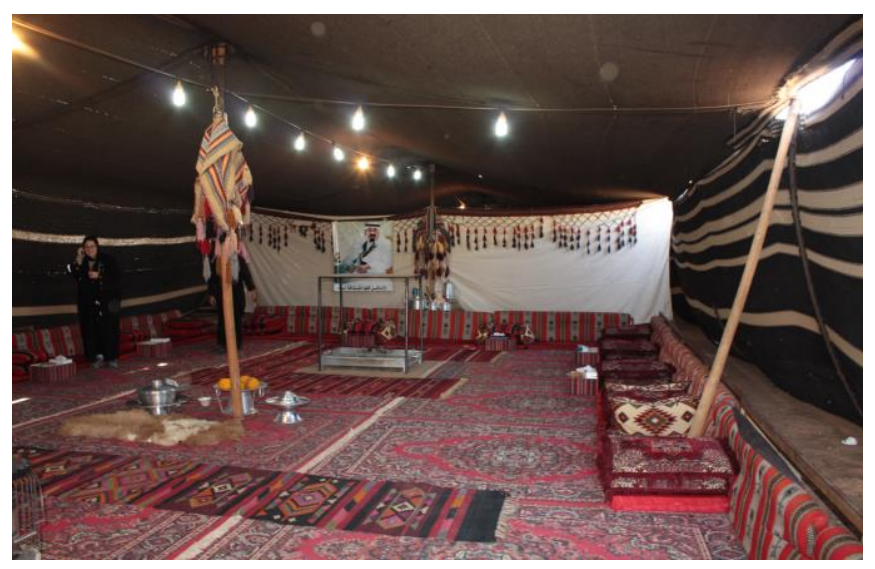

\section{Figure 2. Showing (Bait Al-Sha'r) and the inside divider (Al Gateh).}

The interior of (Bait Al-Sha'r) divider (Al Gateh) is both functional and decorative. The most highly ornamented of (Al Gateh) is facing the men's and guests' sitting room. The (Al Gateh) is very large. It can be twenty-five feet long or longer and six or seven feet high. Furthermore, the dividing curtains are decorated in contrast to the exterior walls, which are plain or simply ornamented. The Beit Al-Sha'r wall is usually made of four or five long, narrow strips, which are sewn together with large iron needles and heavy, highly-twisted yarn. Women usually spin their own sheep's wool and goat hair on hand spindles for (Bait Al-Sha'r).

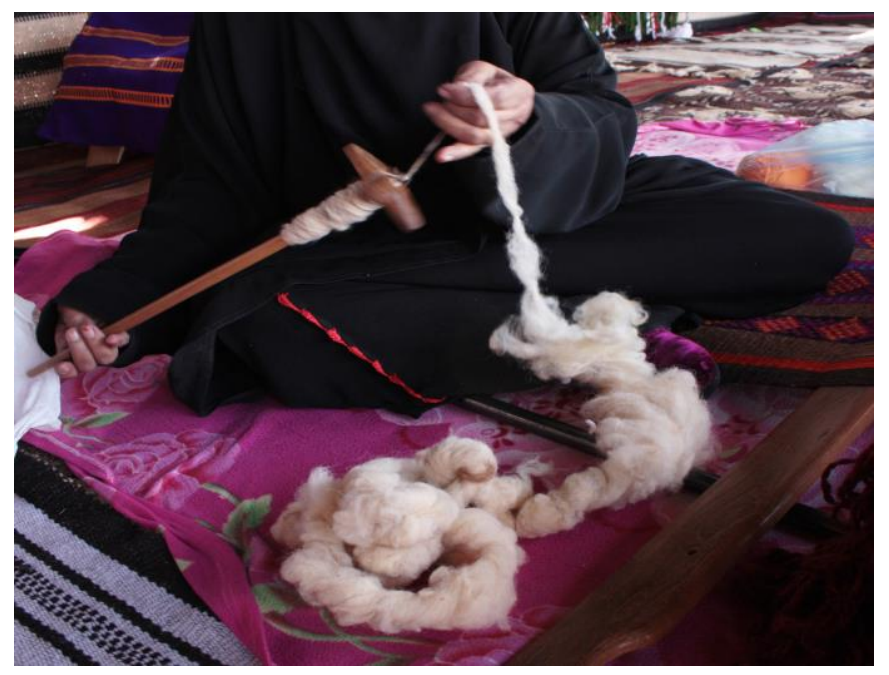

Figure 3. Women weaving of the Goat Hair to make the Fabric of (Bait Al-Sha'r) 
Women occupy a very important position in the Saudi traditional society. Not only do they raise the children, herd the sheep, milk the animals, cook, spin yarn and make the clothes, but they are also in charge of weaving the cloth that constitutes the (Bait Al-Sha'r) and watching over the animals. Furthermore, to raise (Bait Al-Sha'r) the women spread the roof out on the ground and stretch it by tightening the lines attached to the stakes before they hoist the poles. Then they hang the cloth flaps that serve as the walls, with the "door" folded facing away from the wind. The sides are attached to the ground

(Bait Al-Sha'r)' Furniture. Though the furnishings were few, each piece of furniture had its place. the fireplace was built in the exact center of the same spaces and the row of three coffee pots was ranged alongside the hearth, together with the coffee roaster, the wooden tray for cooling the hot coffee beans, the coffee grinder, the incense burner and the host's camel saddle, in case a guest needed a back rest. Sleeping Mattress also are covered by hand made colorful weaving materials and are put on the floor of (Bait AlSha'r) all around the interior wall for people to sit and lean on them.

The lighting is based on the use of the direct light coming from the sun during day time or the moon during night time. Rugs are also used on the floor. They are made out of weaving bright colorful materials for people to sit on them

Residents of (Bait Al-Sha'r) in the Modern World. The number of old residents of (Bait Al-Sha'r) is shrinking today in the new urbanized Saudi Arabia. Many are now settled in the new developed areas. Most of them no longer rely on animals. Centralized authority, borders and the system have undermined their traditional way of life. Roads have decreased their isolation and increased contacts with outsiders. Internet and all media have brought new ideas and exposure to the outside world. Furthermore, the oil industry has changed their lives, who have to deal with oil fields, trucks and other vehicles and machines in areas that were once only desert. However, they still identify themselves as Bedouins (native residents of the desert) and are still trying to maintain ties with their traditional way of living and retain the language and other cultural markers that identify their traditional culture.

Some of them who have adapted to the modern world; retain their tribal loyalties and traditional way of living but in different ways. While they continued to move their herds of camels and goats several times a year to new areas; they no longer depend on their animals for survival. Their lifestyle has changed little during the Kingdom's phenomenal program of modernization. Therefore, as one observe the Kingdom's larger cities, in modern neighborhoods, one often comes upon (Bait Al-Sha'r) constructed in people's gardens -as a symbol of affection for their traditional way of living.

Modern Alteration of traditional patterns of life. The technological advancement along the oil industry that started in the Kingdom of Saudi Arabia at the beginning of the 20th century, have altered traditional patterns of life in the Saudi Arabia. New modern Saudis' behaviors have changed to match the modernized life, however, it is still fashioned by the desert life. Thus, the traditional house (Bait Al-Sha'r) in Saudi Arabia has been developed to house and preserve the main physical characteristics of the Saudi culture.

\section{RESEARCH METHODOLOGY}

This is a descriptive study where data were collected using: personal interviews, digital photography, sketches in addition to the literature review. Al Jouf city was chosen for the purpose of this research because of the familiarity of Al Jouf city and the native residents' life and norms to the researchers. The Al Jouf city is located on the Northern part of the Kingdom.

The researches have chosen the qualitative research methodology due to the importance of the subject and their aim to gather an in-depth understanding of the native residents of the desert' behavior and the reasons 
that govern the way they are using (Bait Al-Sha'r) in their modern contemporary houses. Four cases study were investigated for the purpose of this research from Al Jouf city' residents using the grounded theory methodology to develop a theoretical framework of how how contemporary residents have tried to preserve their inherited traditional and cultural values. A new phenomena was observed by the researchers related to the new use of (Bait al Sha'r) in the new modernized houses.

In addition to that, the researchers adopted a direct observation of how the residents are adopting different ways of preserving the (Bait al Sha'r) in their new modern way of living; without influencing or participating in any way in the respondents' point of views. Many open ended interviews were conducted with the four case studies. The interviews were taped and transcribed and analyzed. Also, the four respondents and their families were able to clarify all their opinions freely. Also, the unstructured interviews with the respondents explored all the topics as they come up. The data collected by the researchers were analyzed using the content analysis methodology looking at the transcribed series of texts and looking for themes and meanings by looking at frequencies of words. The major theme that was very clear in the analysis was the respondents saying we love (Bait Al-Sha'r) because we can see the sky and feel free from the concrete structure that surrounds us in the urban houses where we live today.

\section{CASE STUDIES}

First Case Study. As mentioned earlier, Al Jouf city was used to conduct this study. The first case study chosen was a family living in a traditional (Bait al Sha'r) in the desert surrounding the urbanized housing area. The owner is Om Naeem (mother of Naeem) is a 52 year old lady who indicated that she lived in (Bait Al-Sha'r) until she turned 15 years old with her family, then she got married and had to move with her husband to a new modern house in a new urbanized area. From the analysis of the open ended interviews with Om Naeem it was clear that she cannot stand living in her modern house across from (Bait Al-Sha'r) and that she has created for her and her family this (Bait Al-Sha'r) where we found her with her family and which is located on the peripheries of the city of $\mathrm{Al}$ jouf close to the desert.

Om Naeem added that because she does not like to live in her modern house, she took the advantage of living on the peripheries of the city and used the open desert next to her house to build this (Bait Al-Sha'r) for her family. She indicated that she spends most of her time with her family in (Bait Al-Sha'r) and that she is happy with the fact that she can enjoy the open spaces, the weather, the climate, the sun, the freedom, the privacy and the intimate social life with her family without feeling entrapped in her concrete modern house.

Om Naeem case is a clear indication that the old traditional Saudi residents were forced to change their way of living and that they are still attached to their habits and cultural norms. Furthermore, the location of (Bait Al-Sha'r) in the desert situated on the peripheries of the city is clearly the reason of her feeling free to live her old norms and habits.

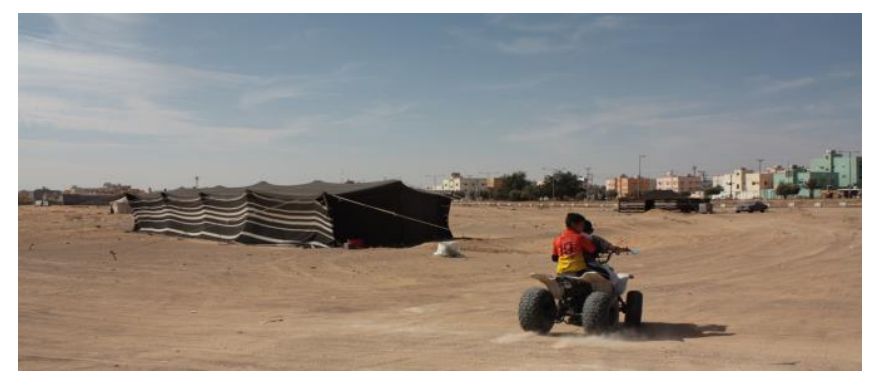

Figure 4. Naeem, her son, playing with the beach bogy around (Bait Al Sha'r) where he spend with his brothers and sisters all their weekends as well as their afternoon after school. 
This picture shows the (Bait Al-Sha'r) and the surrounding open spaces around it, as well as the urban modernized housing areas in the background. It should be added that name himself and his brothers and sisters though indicated that they are enjoying the openness of the area, the sun, the freedom and the climate, however, they miss playing with their PlayStation in their modern house.

Furthermore, Om Naeem case study indicates that although modernization has changed the traditional lifestyle, emphasis is placed on teaching children to carry on traditional ways of life.

Second Case Study. Creation of (Bait Al-Sha'r) next to the modern house.

Abou Karim (father of Karim) house, a new modern villa in Al Jouf city was interviewed all his family.members The participant observation of Abou Karim and his family indicated that the residents have created the (Bait Al-Sha'r) next to their modern house because they feel more comfortable in spending their leisure time there more than inside the modern house. Om Karim, (mother of Karim), indicated that she uses the (Bait Al-Sha'r) for her everyday life way of living. Eating, drinking coffee and entertaining themselves as well as enjoying the freedom they feel in (Bait Al-Sha'r) more that they feel inside the villa. She also indicated that she creates her handcraft work in (Bait Al-Sha'r). Her art work is magnificent and create and preserve the Saudi traditional heritage. Unfortunately, she added that sometimes she has to use synthetic wool which is less expensive from the goat wool which will eventually affect the traditional heritage.

Third case study. It was clear from the third case study that (Bait Al-Sha'r) in the modern world has been developed next to the villas in the urban areas to be used for male entertainment only. It is also clear that they have used the same fabric (Sadou) on the top of a steel structure. This new development of (Bait AlSha'r) clarified the new phenomena of the use of (Bait Al-Sha'r). Thus, eventually the purpose of (Bait AlSha'r) will fade with the modern influence on the old traditional life and habits. tThe male owner of this (Bait Al-Sha'r) was very helpful indicating that he has created it next to the house because it is used for men's gathering and entertainment. It was also clear that women cannot use this (Bait Al-Sha'r) because of its location downtown in the modern house garden as oppose to the first case study where the interviewer indicated that she feels free to move enjoying her privacy and the open spaces around (Bait Al-Sha'r) because of its location in the desert next to her house located on the peripheries of the desert.

Fourth Case Study. A wealthy family from a very well-known tribe in Al Jouf city was visited and all the women of the house were present in their modern villa located down town next to the main Mall of Al Jouf city, They described their modern house pointing to the clear division between the two different sections of men and women and then they indicating that they do not spend time in this fancy villa and they do prefer to go back in the back garden where they built (Bait Al-Sha'r) for themselves. They were from different ages starting from 15 to 75 years old gathered in (Bait Al-Sha'r) feeling free to socialize, to get together, to drink their coffee, enjoying the privacy. The most important issue that came up out of the analysis was how old ladies care so much to teach the young generation their old cultural and traditional habits in (Bait AlSha'r) in order to preserve their norms and traditional heritage. thus, the (Bait Al-Sha'r) is not only used for enjoying old traditional values but it is also used for an educational purposed that the old generations trying to pass on to the new generations.

It is important to indicate that this case study was amazingly surprising because all the respondents were aware of the subject of this research and indicated that they truly believe that they appreciate the purpose of this study because they need people to know more about their old traditional norms of (Bait Al-Sha'r) and the importance of preserving it as a part of their inherited heritage. 


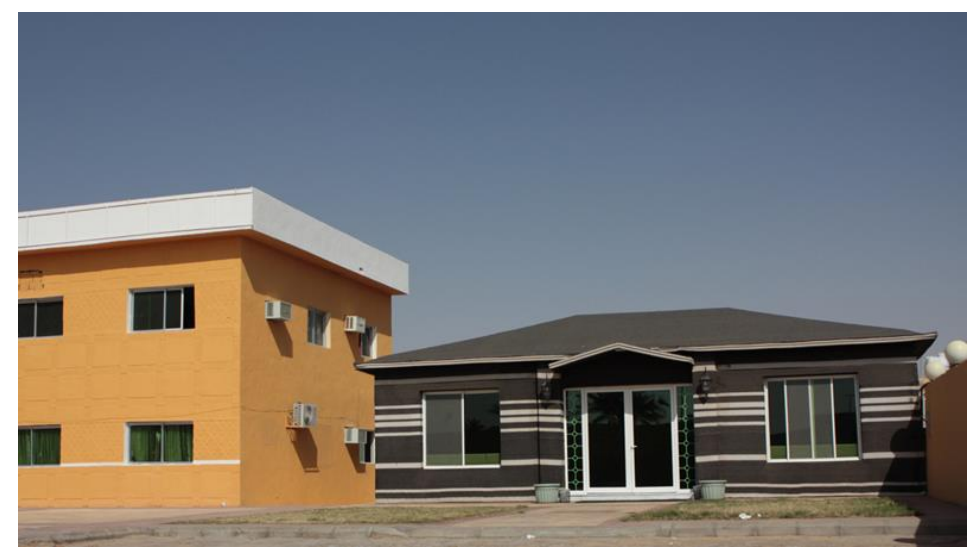

Figure 5. Showing the development of (Bait Al-Sha'r) used as an entertainment area in the new modernized villa courtyard

\section{CONCLUSION}

The results of this research indicate the importance of the preservation of the traditional way of living used by the native residents of the desert before the modernization and oil era in Saudi Arabia as way of preserving their precious heritage. It also points to the importance of the environmental aspects of preserving the climate inside the (Bait Al-Sha'r) manifested in the green way of saving energy and providing healthy and pleasurable environment.

This study indicates that although modernization of the different societies has made the traditional lifestyle less important; it also indicates that the new generation today pitch their (Bait Al-Sha'r) WHICH is their old traditional home in their garden and in the back courtyard of their urban villas where they can adopt their traditional norms. It also indicates that currently the Saudi people are are still using traditional (Bait Al-Sha'r) and have amazingly adopted everyday needs in their way of everyday living. That is, unfortunately with migrations to cities; the use of these dwellings (Bait Al-Sha'r) have dramatically decreased although making it part of the traditional heritage in the Kingdom of Saudi Arabia. The pioneering invention of those people is that they have succeeded to protect their own identity by inventing a new style of life that keeps both traditional and modern way of living. Thus, this research indicate that preserving design heritage is a major part in preserving the country' national identity. A major part of protecting design heritage is to support research studies in this area as well as to encourage design school to incorporate heritage design in their curriculum.

\section{ACKNOWLEDGEMENTS}

Support for this research was provided by all the residents of the Al-Jouf city who were interviewed and their corporation and willingness to demonstrate their cultural needs clarified many ideas for the purpose of this research

\section{REFERENCES}

Abu-Lughod, Lila , (1989). Bedouin Poetry from Sinai and the Negev. London: Saqi Books.

Al-Harbi, T.H. (1989). The Development of Housing in Jeddah: Changes in Built From the

Traditional to the Modern, Unpublished PhD Dissertation, School of Architecture,

University of Newcastle Upon Tyne, UK. 
Al-Hathloul, S. (1981)Tradition, Continuity, and Change in the Physical Environment: The Arab- Muslim City, Unpublished PhD Dissertation, MIT Cambridge, Mass., USA..

Al-Hathloul, S. (1992). Authentication of Modern Architecture, Al-Muhandis, Vol. 5 (2), pp. 46-47. (Arabic).

Al-Hathloul, S. \& Anis-ur-Rahmaam.(1985) The Evolution of Urban and Regional Planning in Saudi Arabia, Ekistics, Vol. 52 (312), May / June, pp. 206- 212.c

Barnard, hans, and Willeke Wendrich, editors. (2008) The Archaeology of Mobility. Nomads in the Old and in the New World. Cotsen, advanced seminars. Los angeles: Cotsen Institute Archaeology.

Caton, Steven, (1990). Anthropology 37: 1-14. "anthropological Theories of Tribe and State Formation in the Middle East Ideology.

Cooper,LLisa (2006)"The Demise and regeneration of Bronze age urban centers in the euphrates valley of syria." in After Collapse: The Regeneration of Complex Societies, edited by glenn $\mathrm{m}$. Schwartz and john $\mathrm{j}$. Nichols, pp. 18-37. Tucson: university of arizona Press.(12) Early Urbanism on the Syrian Euphrates. New York: Routledge.

Creswell, J. W. (2008).Educational Research: Planning, Conducting, and Evaluating Quantitative and Qualitative Research (3rd ed.). Upper Saddle River, NJ: Pearson Education.

Dresch, Paul (1989) Tribes, Government, and History in Yemen. Oxford: Oxford university Press.

Dresch, Paul, and Bernard haykel (1995) "stereotypes and Political styles: islamists and Tribesfolk in yemen." International Journal of Middle East Studies 27 (4 november): Rediscovering the Past in the Present

Qashqa'i (2003) Nomadic Pastoralists and Their use of Land.” in Yeki Bud, Yeki Nabud:Essays on the The cotsen institute of archaeology; The american institute of studies; The university of Pennsylvania museum of archaeology and Anthropology.and semiotics of Power." in Tribes and State Formation in the Middle East, by Philip Khoury and Joseph Kostiner, pp. 74-108. Berkeley: university of California Press.

Sharon B.,"The segmentary Lineage system: a reappraisal." in Changing Nomads in a Changing World, edited by joseph ginat and anatoly m. Khazanov, pp. 94-123. Brighton and Portland: sussex academic Press. Beck, Lois, 1991 Nomad: A Year in the Life of a

http://www.britannica.com/EBchecked/topic/58173/Bedouin 